\title{
Correspondence
}

\section{Corneal and skin changes in tyrosinaemia}

\author{
TO THE EDITOR British Fournal of Ophthalmology
}

SIR, In I973 a paper was published on the subject of corneal changes in tyrosinaemia and skin changes, and the corneal changes in circumscribed palmo-plantar keratoderma were discussed (Westmore and Billson, 1973). The purpose of this letter is to draw attention to a paper describing the subsequent course of the patient who was found to have tyrosinaemia (Billson and Danks, 1975). In this patient high voltage electrophoresis of urine showed heavy excretion of tyrosine. Tyrosyluria was demonstrated by gas liquid chromatography and confirmed by mass spectrometry. Serum tyrosine ranged from 22 to $28 \mathrm{mg} / \mathrm{dl}$ ( 398 to $507 \mathrm{mmol} / \mathrm{l}$ ) on her normal diet, which turned out to have a relatively low protein content (estimated at less than $2 \mathrm{~g} / \mathrm{kg}$ per day). A tyrosine load of $150 \mathrm{mg} / \mathrm{kg}$ caused the serum tyrosine to rise to $38 \mathrm{mg} / \mathrm{dl}(699 \mathrm{mmol} / \mathrm{l})$ and this was accompanied by intense pain in the eyes, hands, and feet so that the patient could not walk. A rim of intense erythema developed around the skin lesions. Restrictions of the phenylalanine and tyrosine intake to $40 \mathrm{mg} / \mathrm{kg}$ a day of each using a diet based on Albumaid X-PT (Scientific Hospital Supplies Ltd) resulted in a decrease in the serum tyrosine and relief of the discomfort in the eyes and skin within 24 hours. The serum tyrosine has been maintained in the range of 5 to $10 \mathrm{mg} / \mathrm{dl}$ for six months. The eye lesions have healed and the skin changes have now resolved completely.

The association of herpetoid corneal ulceration and circumscribed palmo-plantar keratoderma, separately and together, with tyrosinaemia has been reviewed by Goldsmith, Kang, and Bienfang (1973). There is one further patient in Melbourne with a similar type of tyrosinaemia who is retarded. He has no skin or eye lesions (Louis, Pitt, and Davies, 1974), but he developed pain in the eyes and feet during a tyrosine load test.

The patient who is the subject of this letter is clinically remarkable among cases reported because of the mild degree of her mental retardation. Clearly tyrosinaemia should be considered in all patients with the Richner-Hanhart syndrome or with either of its components, whether or not they are retarded.

Yours faithfully, F. A. BILLSON, D. DANKS

Royal Children's Hospital,

Department of Ophthalmology and Pediatrics,

Flemington Road,

Parkville 3052, Australia

2 August 1976

\section{References}

BILlson, F. A., and DANKs, D. (1975) Aust. F. Ophthal., 3, II 2

GoldSMith, L. A., KANG, E., and BIENFANG, D. C. (I973) F. Pediat., 83, 798

Louis, w. J., PITT, D. D., and Davies, H. (1974) Aust.

N.Z. F. Med., 4, 281

WESTMORE, R., and BILlson, F. A. (1973) Brit. $\mathcal{F}$.

Ophthal., 57, 654

\section{Book reviews}

Diabetic Retinopathy. By S. RIASKoff. I 976. Pp. 64, 39 colour illustrations, I table, refs. Junk, The Hague ( DG $_{50}$ )

Diabetic retinopathy has been classified by a method based on that of Oakley, and standard pictures serving as examples of moderate and marked lesions in diabetic retinopathy have been prepared. By comparing the signs present in a fundus with those of the standard photographs, the observer is helped to decide on the severity of the case and its prognosis. The standard photographs are in colour and are sufficiently numerous to show all the common lesions of diabetic retinopathy in some detail.

There is a smaller section on the actual treatment of the lesions. The author advocates the coagulation of all visible lesions-including haemorrhages, microaneu- rysms, new vessels, and pockets of subhyaloid haemorrhage - and it is noticeable that he follows the trend towards extensive retinal ablation.

The monograph is well thought out and produced and will be of great value in training the new generation of ophthalmologists who will be spending an increasing amount of their time treating diabetic retinopathy.

J. H. DOBREE

Korrektive Dermatologie. By J. Petres and M. Hundeiker. I975. Pp. II I, 84 figs, 2 I tables, bibliog. Karger, Basel (DM58)

This book aims at a broad review of the techniques of plastic surgery with specific reference to the dermatological lesions it is desired to remove. Hence it begins with a list of those lesions which may be encountered 